\title{
EFFECTS OF STATIC MAGNETIC FIELD ON Escherichia coli MUTATION
}

\author{
Fouad Houssein Kamel \\ Medical Technical Institute, Erbil. \\ Polytechnic University, Erbil, Iraq. \\ Ashti M. Amin, Saleem Saaed Qader \\ Hawler Medical Research Centre, Erbil \\ University, Iraq. \\ E-mail:fhkamel2013@yahoo.com
}

\begin{abstract}
The effects of a dipolar static magnetic field of strength 400, 800, 1200 and 1600 Gauss were prepared locally, on the ultra-structure of E. coli type 1 bacterium cells have been studied. Equal volumes of liquid culture media were exposed to the magnetic field for different periods, the three most effective periods, namely: $24 \mathrm{hrs}, 48 \mathrm{hrs}$ and $72 \mathrm{hrs}$ were chosen for all our experimental studies. After API kit test of treated E. coli culture media as control group. Results indicated that exposure of the microorganisms to the demonstrated magnetic field caused pronounced changes in the Arginine dihydrolase (ADH), Citrate utilization (CIT) and Gelatinase (GEL) were observed on the cell growth. Besides, changes in the morphology of the E. coli colonies were observed after exposure period and subculture on MacConkey agar. Furthermore, the bacterial growth subculture tested for morphological and biological activity, the results suggested that a mutation occurred in bacterial cells.
\end{abstract}

Keywords: Magnetic field; optical density; E coli; mutation.

Received: 16/7/2013, Accepted: 24/3/2014.

\section{INTRODUCTION}

A magnetic field is the area of influence exerted by a magnetic force. This field is normally focused along two poles. These poles are usually designated as north and south. However these directions are not the only two that a magnetic field can have, most magnetic objects are composed of many small fields called domains. The search for a biological effect due to magnetic fields has a long history dating back a hundred years. The literature on biomagnetic effects on the growth and development of various organisms has been quite extensive showing both positive and negative findings. Among the positive findings attributed to strong magnetic fields are: altered growth rate, enzyme activities, cellular metabolism, DNA synthesis and animal orientation (Gremion et al, 2009).

A wide variety of methods have been reported in the literatures which are directed to the use of magnetic energy as a diagnostic technique and also for the treatment of diseases in warm blooded animals including humans. For example, magnetic energy has been utilized quite successfully over the past several years to promote the formation of osteoblasts in conjunction with the healing of bone fractures. In many instances markedly improved results in healing times have been achieved by the application of magnetic energy to the site of bone fractures and other injuries. Magnetic enhancement or retardation of bacterial or cellular growth rates has been reported in the literature. For example, Davis and Rawls presented numerous examples of enhancement to seeds and various types of cellular growth (Albert et al, 1996). Magnetic inhibition of bacterial growth in wounds healing reported by (Henry. et $a l$, 2008). Investigations sponsored by Bio-Magnetics Systems, Inc. have shown that unidirectional magnetic fields inhibited or increased the growth of cancer cells, depending on the field polarity (Trappier et al. 1990).

A mutation is a permanent change in the DNA sequence of a gene. Mutations in a gene's DNA sequence can alter the amino acid sequence of the protein encoded by the gene (Rosche et al. 2000). 
Mutations can be acquired. This happens when environmental agents like magnetic field forces damage DNA, or when mistakes occur when a cell copies its DNA prior to cell division (Ji et al, 2009).

\section{MATERIALS AND METHODS}

Bacterial suspension of $E$ coli isolated from human urine sample and cultured on MacConkey agar will be inoculated into five groups of tubes containing nutrient broth media and exposed four tubes to one of dipolar magnetic field which were prepared locally with different forces including 400, 800, 1200, $1600 \mathrm{G}$ and measured by Teslometer in Physical Department /College of Science. The tube number five regard as a control and not subjected to magnetic power, all of these tubes incubated separately for 24,48 and 72 hours at $37^{\circ} \mathrm{C}$. The inoculation of API kit (BioMerieux Company) with bacteria from each groups were performed separately to identify the enteric bacteria type (Appelbaum et al, 1980, A plastic strip holding twenty mini-test tubes inoculated with a saline suspension of a pure culture. This process also rehydrates the desiccated medium in each tube. A few tubes are completely filled (CIT, VP and GEL, and some tubes overlaid with mineral oil such that anaerobic reactions can be carried out (ADH, LDC, ODC, H2S and URE) (Lindquist et al., 2001).

After incubation in a humidity chamber for $18-24$ hours at $37^{\circ} \mathrm{C}$, the color reactions were read. Note especially the color reactions for amino acid decarboxylations (ADH through ODC) and carbohydrate fermentations (GLU through ARA). The amino acids tested are (in order) arginine, lysine and ornithine. Decarboxylation is shown by an alkaline reaction (red color of the particular $\mathrm{pH}$ indicator used). The carbohydrates tested are glucose, mannitol, inositol, sorbitol, rhamnose, sucrose, melibiose, amygdalin and arabinose. Fermentation is shown by an acid reaction (yellow color of indicator). Hydrogen sulfide production $\left(\mathrm{H}_{2} \mathrm{~S}\right)$ and gelatin hydrolysis (GEL) result in a black color throughout the tube. A positive reaction for tryptophan deaminase (TDA) gives a deep brown color with the addition of ferric chloride (Lindquist et al 2001). The enzymes ADH, CIT and GEL of API test from all groups are affected by magnetic field, one drop of this bacterial suspension and was inoculated added to $5-\mathrm{ml}$ nutrient broth media, incubated for $24 \mathrm{hrs}$ without magnetic field at $37^{\circ} \mathrm{C}$, performing API test, subculture on MacConkey agar and measured the OD again to determine the mutation or inhabitation of bacterial sample.

\section{RESULTS AND DISCUSSION}

Changes in the structure and characteristic behavior of bacteria resulting from the exposure to the static magnetic field have been reported. These results may be of a great importance for evaluating the benefits and hazards of exposure to the static magnetic field. Also the importance of this work lays in the fact that $E$. coli as a microorganism is a unit cell behaving as a complete living biological system. (Table 1 and Fig 1); shows the change in the E.coli type 1 enzymes such as ADH, CIT and GEL. It is clear from this table and figure that the24 hrs exposure period to different forces of SMF (400, 800, 1200 and 1600) G can inhibit or promote enzyme activity according to API test, these results are in a good agreement with (Gremion et al, 2009). The literature on biomagnetic effects on the growth and development of various organisms has been quite extensive showing both positive and negative findings. Among the positive findings attributed to strong magnetic fields are: altered growth rate, enzyme activities, cellular metabolism, DNA synthesis and animal orientation. Also (Saunders et al, 1991) reported that the biological effects of magnetic fields may critically depend on the physical characteristics of the magnetic signal, in particular the wave forces. Many studies indicated that magnetic field has a biological effect on living things (Gremion et al, 2009). . 
Table (1): The API test for E. coli samples \pm magnetic forces at 24 hours

\begin{tabular}{|c|c|c|c|c|c|c|c|c|c|c|c|c|c|c|c|c|c|c|c|c|}
\hline そֶ & 要 & ב & ठิ & 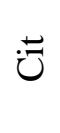 & Iี & $\frac{1}{\alpha}$ & 芯 & 主 & $\stackrel{p}{>}$ & 牙 & 己ְ & $\sum^{\Xi}$ & $\stackrel{0}{Z}$ & $\begin{array}{l}\frac{1}{0} \\
\text { n }\end{array}$ & $\underset{\simeq}{\mathbb{a}}$ & 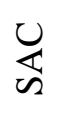 & $\stackrel{\overrightarrow{1}}{\Sigma}$ & $\sum_{<}^{2}$ & $\frac{\mathbb{2}}{<}$ & $\begin{array}{c}24 \\
\text { hours }\end{array}$ \\
\hline+ & + & + & + & - & - & - & + & + & - & - & + & + & - & + & + & + & + & - & + & Control \\
\hline+ & - & + & + & + & - & - & + & + & - & - & + & + & - & + & + & + & + & - & + & $\begin{array}{c}400 \\
\text { Gauss }\end{array}$ \\
\hline+ & - & + & + & + & - & - & + & + & - & + & + & + & - & + & + & + & + & - & + & $\begin{array}{c}800 \\
\text { Gauss }\end{array}$ \\
\hline+ & - & + & + & + & - & - & + & + & - & - & + & + & - & + & + & + & + & - & + & $\begin{array}{c}1200 \\
\text { Gauss }\end{array}$ \\
\hline+ & - & + & + & + & - & - & + & + & - & - & + & + & - & + & + & + & + & - & + & $\begin{array}{c}1600 \\
\text { Gauss }\end{array}$ \\
\hline
\end{tabular}

Table (2): The API test for E. coli at 48 and 72 hours

\begin{tabular}{|c|c|c|c|c|c|c|c|c|c|c|c|c|c|c|c|c|c|c|c|c|}
\hline ○ & 要 & בِ & ठิ & $\ddot{U}$ & 气ิ & 壳 & 芯 & 立 & 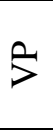 & 焉 & 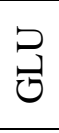 & $\sum_{\Sigma}^{\Xi}$ & 吕 & 号 & $\underset{\mathbb{2}}{\mathbb{\Omega}}$ & 崫 & $\stackrel{\overrightarrow{\mid l}}{\sum}$ & $\sum_{i}^{2}$ & $\frac{\mathbb{2}}{<}$ & $\begin{array}{c}48 \& 72 \\
\text { hours }\end{array}$ \\
\hline+ & + & + & + & - & - & - & + & + & - & - & + & + & - & + & + & + & + & - & + & Control \\
\hline+ & - & + & + & + & - & - & + & + & - & - & + & + & - & + & + & + & + & - & + & $\begin{array}{c}400 \\
\text { Gauss } \\
\end{array}$ \\
\hline+ & - & + & + & + & - & - & + & + & - & - & + & + & - & + & + & + & + & - & + & $\begin{array}{c}800 \\
\text { Gauss }\end{array}$ \\
\hline+ & - & + & + & + & - & - & + & + & - & - & + & + & - & + & + & + & + & - & + & $\begin{array}{c}1200 \\
\text { Gauss }\end{array}$ \\
\hline+ & - & + & + & + & - & - & + & + & - & - & + & + & - & + & + & + & + & - & + & $\begin{array}{c}1600 \\
\text { Gauss }\end{array}$ \\
\hline
\end{tabular}

Table 3 shows the growth rate of $E$. coli for each groups incubated in magnetic determined by spectrophotometer. There is a decrease in the growth rate of the exposed $E$. coli cells to different magnetic field forces. Kohno et al. (2000) reported ferrite magnet caused strength dependent decrease in the growth rate and maximum number of bacteria for $S$. mutans, $S$. aureus when cultured under anaerobic conditions but their growth was not inhibited under aerobic conditions. However no growth effects were detected in $E$. coli culture which was contrary to our result, the static magnetic field affected the growth rate of E. coli. . Table( 4) and figure 3 (A and B). Shows that the growth rate of E. coli for each groups incubated without magnetic fields are determined by spectrophotometer. The $800 \mathrm{G}$ bacterial suspension incubated again without magnetic field at $24 \mathrm{hrs}$, resulted in the mutation of E. coli growth, because the enzyme gelatinase can be affected again by magnetic field, and the colony size of bacteria on media agar was changed and the growth rate also decreases. We found obvious cell surface damage when the cells were exposed to SMFs. . Mutations can be caused by mistakes in DNA replication or by damage to DNA Portier et al,1998). We reported that MF exposures did not increase mutation rates in any tester strain although other investigators have reported that power frequency MFs can alter fidelity of replication via a defect on DNA repair systems. For instance (Henry L et. al, 2004) reported that $60 \mathrm{~Hz}, 0.1-$ $0.5 \mathrm{mT}$ magnetic fields inhibit DNA repair in rat cells in vivo. Gui et al. (2001) reported that the higher density $50 \mathrm{~Hz} \mathrm{MF}(400 \mathrm{mT})$ affects DNA repair in a human cell line, and that the mutation frequency varies with induced current. 
Table (3): The growth rate of E.coli for each groups incubated in magnetic field are determined by spectrophotometer

\begin{tabular}{|c|c|c|}
\hline $\begin{array}{c}\text { Samples incubation in different } \\
\text { MF forces }\end{array}$ & OD 600nm at 24 hours & Bacterial cell count X 10 \\
\hline control & 1.192 & 715.2 \\
\hline $400 \mathrm{G}$ & 1.403 & 841.8 \\
\hline $800 \mathrm{G}$ & 1.120 & 672 \\
\hline $1200 \mathrm{G}$ & 1.080 & 648 \\
\hline $1600 \mathrm{G}$ & 1.112 & 667.2 \\
\hline
\end{tabular}

Table (4): The growth rate of E.coli for each groups incubated without magnetic fields are determined by spectrophotometer

\begin{tabular}{|c|c|c|}
\hline Samples incubation & OD 600nm at 24 hours & Bacterial cell count X 10 \\
\hline control without magnetic field & 1.192 & 715.2 \\
\hline $400 \mathrm{G}$ & 1.200 & 720 \\
\hline $800 \mathrm{G}$ & 0.110 & 66 \\
\hline $1200 \mathrm{G}$ & 0.010 & 60 \\
\hline $1600 \mathrm{G}$ & 0.123 & 73.8 \\
\hline
\end{tabular}

Fig (3): A. Treated E.coli culture with $800 \mathrm{G}$ magnetic field.

B. E.coli culture without magnetic field (mutation occur from A large to B small colony size).

A

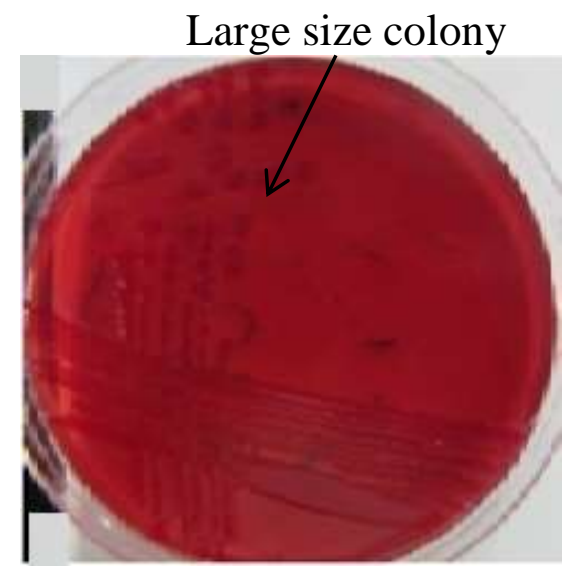

B

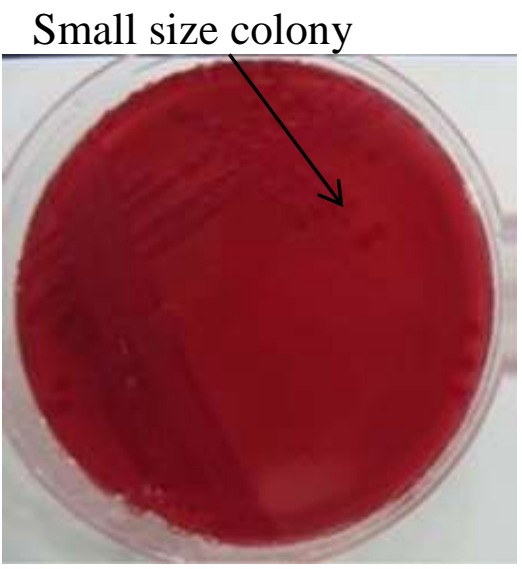

The different forces of static magnetic field affect the growth rate, and enzyme activity of E. coli. $800 \mathrm{G}$ static magnetic field was mutagenic to $E$. coli type 1 .

ACKNOWLEDGMENT: We gratefully acknowledge the support of the Rizgari Teaching Hospital laboratories for sample collection. Grateful thanks for the Medical Research Center's technician group, and also to Ms. Sazan Qadir, PhD student, Science College for her help in the analysis.

$$
\begin{aligned}
& \text { تأثير المجال المغناطيسي الثابت على طفرات البكتريا الايشيريشيا القولونيه } \\
& \text { اثتني محمد أمين سليم سعيد قادر المبر } \\
& \text { مركز البحوث ألطبية جامعة هولير الطبية }
\end{aligned}
$$

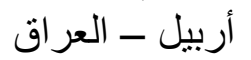

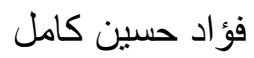

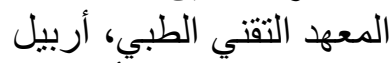

$$
\begin{aligned}
& \text { جامعة بولي تكنيك هولير، أربيل - العربل القيل }
\end{aligned}
$$

E-mail:fhkamel2013@yahoo.com 


\section{الخلاصة}

درست تأثثير المجال المغناطيسي ثنائي القطب وبقوى 1600،1200،800،400 كاوس المحضرة محليا

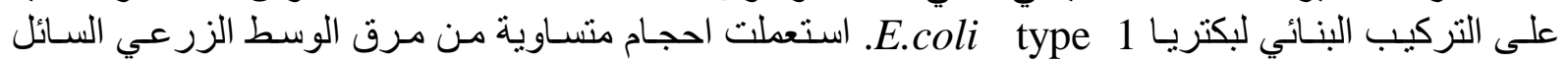

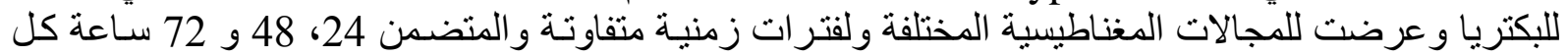

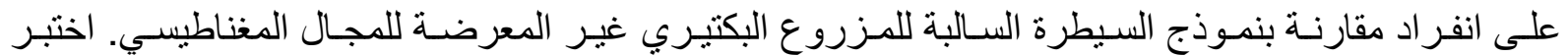

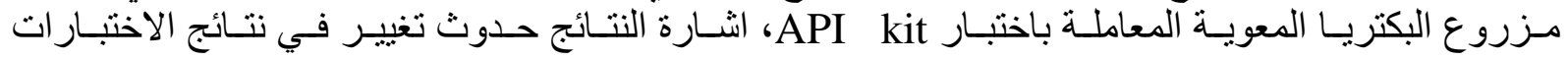
Arginine dihydrolase (ADH), Citrate utilization (CIT Gelatinase (GEL))

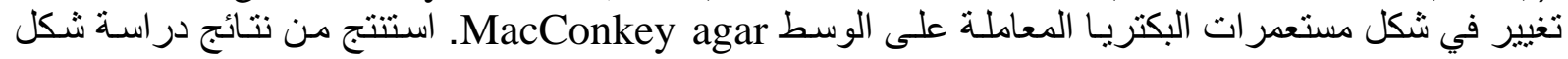

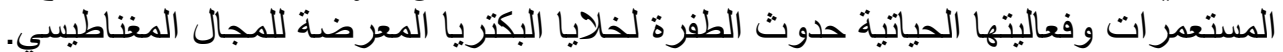

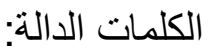

تاريخ تسلم البحث: 2013/7/16 ، وقبوله: 2014/3/24.

\section{REFERENCES}

Albert R.D, C.R Jr Walter, (1996). Magnetism And Its Effects On The Living System, U.A.S., Edition: 2nd .

Appelbaum PC, Stavitz J, MS Bentz (1980). Four methods for identification of gramnegative no fermenting rods: Organisms more commonly encountered in clinical Specimens. Journal Clinical Microbiology, 12: 271-8.

Gremion G, Gaillard D, PF Leyvraz (2009). Effect of biomagnetic therapy versus physiotherapy for treatment of knee osteoarthritis: a randomized controlled trial. Department of Orthopedic Surgery (DAL), Centre Hospitalier Universitaire Vaudois, University of Lausanne, Lausanne, Switzerland, 41:1090-5.

Gui R, W Kanako, T Masao, M Junji (2001).Increase in hypoxanthine-guanine phosphoribosyl transferase gene mutations by exposure to electric field. Life sciences. 68 (9): 1041- 46.

Henry L, P. Narendra (2004). Magnetic field induced DNA strand breaks in brain cells of the rat. Environmental Health Perspectives, 112:687-694.

Hey J, Posch A, A. Cohen (2008). Fractionation Of Complex Protein Mixtures By Liquid Phase Isoelectric Focusing. Bio-Rad Laboratories, Inc., Hercules, California, USA, 424: 225-39.

Ji W, Huang H, A Deng (2009). Effects of static magnetic fields on Escherichia coli. Micron, 40(8): 894-898.

Kohno MF, Yama ZA, I Kmura (2000). Effect of static magnetic field Streptococcus mutants and E.coli. Pathophysiology, 17: 143-148.

Lindquist J, J Sawyer (2001). An Introduction To Bacterial Identification. Department of Bacteriology, University of Wisconsin-Madison, ET14.9, 4.3, 5.0.

Portier C.J, M.S Wolfe (1998).Assessment Of Health Effects From Exposure To Power Frequency Electric And Magnetic Fields. Niehs working group report, NIH Publication no. 98-3981.

Rosche WA, PL Foster (2000). Determining Mutation Rates in Bacterial Populations Department of Biological Science, University of Tulsa, and 600 South College Avenue, Tulsa, Oklahoma 74104-3126, USA: 4-17.

Saunders RD, Seinkiewicz ZJ, CI Kowalczuk (1991): Biological effects of electromagnetic fields and radiation. Journal of Radiological protection 11:27-42. 
Trappier A, Lorio P, L. P Johnson (1990). Evolving Perspectives On The Exposure Risks From Magnetic Fields, Journal of the National Medical Association, 82: 621-624. 